\title{
Merkel cell carcinoma. A review
}

\author{
Richard Pink ${ }^{\mathrm{a}}$, Jiri Ehrmann ${ }^{\mathrm{b}}$, Martin Molitorc, Peter Tvrdy ${ }^{\mathrm{a}}$, Petr Michl ${ }^{\mathrm{a}}$, Jindrich Pazdera ${ }^{\mathrm{a}}$, Jan Hanuliak ${ }^{\mathrm{a}}$
}

Background. Merkel cell carcinoma (MCC) is a rare potentially fatal skin tumour affecting older mainly white people and younger immunosuppressed individuals. While uncommon, the incidence is increasing relative to melanoma and with twice the lethality. The benign appearance of the tumour usually on exposed skin parts, contrasting with its extensive microscopic invasion, can delay timely diagnosis. Recurrent MCC is currently attributed to the recently discovered Merkel cell polyomavirus This brief review of MCC covers the history, epidemiology,etiology,clinical and histological features, treatment and prognosis.

Methods. Literature search using PubMed and search words Merkel cell carcinoma (MCC), etiology, treatment for the years 1972 to 2010.

Results and conclusion. Merkel cell carcinoma is a rare malignancy with uncertain prognosis. Due to the uncommon occurrence and dearth of randomized studies, there is no agreement on optimal treatment. The tumor has only recently been included in the international classification of tumors (NCCN). The treatment approaches found to be best are radical surgery of primary tumor, drainage of lymph node extension and possibly adjuvant loco-regional radiotherapy. The basis of successful treatment however, remains prevention regular dermatological examination in immunosuppressed patients and early initiation of combination therapy, based on radical surgery supplemented by radiotherapy and palliative chemotherapy in the last resort.

Key words: merkel cell carcinoma (MCC), etiology, treatment

Received: November 1, 2011; Accepted: February 28, 2012; Available online: June 1, 2012 http://dx.doi.org/10.5507/bp.2012.033

${ }^{a}$ Department of Oral and Maxillofacial Surgery, University Hospital Olomouc, Czech Republic

${ }^{b}$ Department of Pathology, Faculty of Medicine and Dentistry, Palacky University Olomouc and University Hospital Olomouc 'Department of Plastic and Aesthetic Surgery, Faculty of Medicine and Dentistry, Palacky University Olomouc and University Hospital Olomouc

Corresponding author: Richard Pink, e-mail: richard.pink@seznam.cz

\section{INTRODUCTION}

Merkel cell carcinoma (MCC) is a malignant neuroendocrine tumor first described by Toker in 1972 as a "trabecular carcinoma of the skin" from its characteristic microscopic structure ${ }^{1}$. The term "Merkel cell carcinoma" was used prior to the 1980s but the tumor had been known under various synonyms before this. Merkel cells, located in the basal layer of the epidermis and hair follicle form a picture of large light cells, synaptically connected to the sensory nerve endings ${ }^{1}$. In vertebrates, Merkel cell nerve endings are cutaneous mechanoreceptors but the origin of Merkel cells is unclear. They may originate in the epidermal epithelial cells or neural crest from where they later migrate into the epidermis. Their differentiation from the main pluripotent cells is dependent on the essential transcription factor Atoh1 (factor atonal hemo$\log 1)\left(\right.$ ref. $\left.^{2}\right)$

\section{Epidemiology, etiology}

Merkel cell carcinoma is rare,with an incidence of around 5 cases per 1 million population and extremely rare in childre ${ }^{3,4}$. Though the trend is increasing, it is many times rarer than malignant melanoma ${ }^{5}$ occurs mainly in people older than 65 , more in men and those with immune dysfunction due to cancer, HIV infection or transplantation. The high incidence of post transplant malignancies is closely related to the length and type of immunosuppressive therapy used as a number of studies have shown that the intensity of the immunosuppression is directly related to the incidence of post transplant tumours ${ }^{6,10}$. Immunosuppression has been shown to lead to DNA damage ${ }^{7}$. Some post-transplantation malignancies are related,to oncogenic viruses (eg EBV, HPV and $\mathrm{MCPyV}$ ( ref. $^{8}$ ) and in transplantation patients there is increased metastatic potential via blood, lymphatic and perineural invasion ${ }^{9,10}$.

For MCC, described is also the simultaneous occurrence of other tumors such as breast and ovarian cancer, blood malignancies and anaplastic meningiomas. One likely trigger is UV radiation ${ }^{11}$.

In the etiology of MCC, several chromosomal abnormalities have been described, the most common being chromosomes 1,6,11 and 16 but the best known are trisomy of chromosomes 1 and 6. DNA alterations have been reported primarily in advanced tumors with a threefold risk of metastasis overtumors without involvement of DNA. Recurrent malignant Merkel cell tumours have recently been connected to infection with the "Merkel cell polyomavirus" (MCPyV) ( ref. $^{8}$ ) 


\section{Clinical and histological features}

Merkel cell carcinoma occurs mainly on the face and neck (40-60\%), followed by the trunk (33\%) and rarely on the extremities (10-20\%) (ref. $\left.{ }^{12}\right)$.On the face the main sites are the cheeks and eyelids but it also occurs on the lips, forehead and nose. The literature also describes the gluteal area where it may mimic a cyst and cause late diagnosis ${ }^{13}$. Clinically it manifests as a solid, painless tumor exophytic in character, skin colored, sometimes reddish, with a very aggressive growth ${ }^{14,15}$. The flat form may also occur. The differential diagnosis must involve distinction from basocellular and squamous cell carcinoma which are common skin malignancies in parallel or skin metastasis from another primary site. Other possibilities are malignant lymphoma, keratoakanthoma, amelanoblastic melanoma and deeply located parts of a cyst ${ }^{13}$. A tumor that has been removed very often recurs locally and metastasizes early to lymph and blood vessels. The incidence of malignancies of any duplicate (see above) significantly worsens the prognosis and mortality increases several times. The macroscopically seemingly enclosed form of the cancer contrasts with its tendency to microscopic spread to distant sites. Most of the nodules are localized tumors in the dermis: only 10\% of Merkel cell tumors are intraepithelial. The cytological picture is characterized by dull, monotonous medium size nuclei with numerous mitoses. Histologically there are three types of tumor. The trabecular type, described as a typical Toker trabeculae construction involving adnexa such as hair folicules ${ }^{1}$. This is the least frequent. The intermediate type and variant based on small cells occur more frequently and are much more malignant ${ }^{16,17}$ Exceptionally, there is no transitional form of the cancer.

Immunohistochemically, the tumor can be marked with the help of epithelial and neuroendocrine markers. Epithelial markers include low molecular weight cytokeratins $(8,18,19,20)$ of which for diagnosis, the major one is cytokeratin $20(\mathrm{CK}-20)\left(\right.$ ref. $\left.^{18,19}\right)$. CK - 20 is formed in the epithelial cells of the gastrointestinal and urinary system and Merkel cells. However, in $5 \%-25 \%$ of MCC, CK-20 positivity is not found. Another epithelial marker which controls the determination and differentiation of cells is thyroid transcription factor 1 (TTF - 1), consisting of epithelial cells of the thyroid gland, lung and

Table 1. Use of immunohistochemical markers in the diagnosis of Merkel cell carcinoma (source: Koljonen, Merkel cell carcinoma, World Journal of Surgical Oncology 2006,4:7).

\begin{tabular}{lcccccccccc}
\hline & CK-20 & TTF-I & NSE & S-100 & GrA & SYP & NFP & CD56 & MAP-2 & LCA \\
\hline MCC & + & - & + & - & $+/-$ & $+/-$ & + & + & + & - \\
SCLC & - & + & $+/-$ & - & $-/+$ & + & $-/+$ & + & + & - \\
MM & - & - & - & + & - & & - & & + & - \\
LGNEC & + & & + & & + & + & $-/+$ & & & \\
Malignant & - & - & - & - & - & & $-/+$ & & & \\
lymphoma & & & & & & & & & & \\
\hline
\end{tabular}

+ positive, + / - Mostly positive, + / - Mostly Negative - Negative. CK20 - cytokeratin 20, TTF I - thyroid transcription factor I, NSE -neuronspecific enolase, GRA - chromogranin A NFP -neurofilament proteins, CD56 - neural adhesion molecule, MAP-2 microtubule associated protein, LCA - leukocyte common antigen,SCLC -small cell lung carcinoma, MM - malignant melanoma,LGNEC - low-grade neuroendocrine carcinomas.

Table 2. The prognosis.

\begin{tabular}{|c|c|c|c|c|}
\hline & $\mathrm{T}$ & $\mathrm{N}$ & M & 5 year survival \\
\hline Stadium 0 & Carcinoma in situ & $\begin{array}{c}\text { Regional metastasis } \\
\text { absent }\end{array}$ & $\begin{array}{c}\text { Distant metastasis } \\
\text { absent }\end{array}$ & \\
\hline Stadium I & $>2 \mathrm{~cm}$ & $\begin{array}{c}\text { Regioal metastasis } \\
\text { absent }\end{array}$ & $\begin{array}{c}\text { Distant metastasis } \\
\text { absent }\end{array}$ & $81 \%$ \\
\hline Stadium II & $<2 \mathrm{~cm}$ & $\begin{array}{c}\text { Regional metastasis } \\
\text { absent }\end{array}$ & $\begin{array}{c}\text { Distant metastasis } \\
\text { absent }\end{array}$ & $67 \%$ \\
\hline Stadium III & $\begin{array}{l}\text { Regardless of } \\
\text { tumour size }\end{array}$ & $\begin{array}{l}\text { Regional metastasis } \\
\text { present }\end{array}$ & $\begin{array}{c}\text { Distant metastasis } \\
\text { absent }\end{array}$ & $52 \%$ \\
\hline Stadium IV & $\begin{array}{l}\text { Regardless of } \\
\text { tumour size }\end{array}$ & $\begin{array}{l}\text { Regional metastasis } \\
\text { present }\end{array}$ & $\begin{array}{l}\text { Distant metastasis } \\
\text { present }\end{array}$ & $11 \%$ \\
\hline
\end{tabular}


brain $^{20}$. It is mainly used in the differential diagnosis of MCC and small-cell lung cancer where the TTF is positive and CK - 20 negative ${ }^{21}$.

One standard marker used in the diagnosis of neuroendocrine tumors is neuron-specific enolase (NSE) $\left(\right.$ ref. $\left.^{22,23}\right)$. More recently, markers used in the diagnosis of MCC are CD56 and NCAM (neural cell adhesion molecule) (ref. ${ }^{24-26}$ ). Likewise, chromogranin $\mathrm{A}(\mathrm{CrA})$ is another representative marker in the diagnosis of endocrine tumors $^{26}$. MCC is demonstrated by positive immunoreaction to CrA. Recently discovered neuroendocrine markers are microtubule-associated proteins (MAPS) which form part of the microtubule cytoskeleton of proteins in the peripheral and central nervous system ${ }^{27,28}$. Most often used is the MAPS - 2 marker which has high sensitivity and specificity. Liu et al. ${ }^{26}$ found a positive MAPS - 2 in all patients with MMC while the marker CK - 20 was not in all cases conclusive. In general, we can say that MCC shows itself as a neuroendocrine tumour. The immunohistochemical distinction between Merkel cell carcinoma and other malignancies is shown in Table 2.

In microscopic images, it is necessary to distinguish between undifferentiated carcinoma, metastasisof lung carcinoma, small cell lymphoma, Ewing sarcoma, rhabdomyosarcoma, neuroblastoma, osteosarcoma and chondrosarcoma ${ }^{29-31}$.

\section{Treatment and prognosis}

To determine the stage of disease, the recommendation, as in the case of malignant melanoma is PET investigation, to exclude locoregional and distant metastases. For a large microscopic tumor progression in the surrounding areas, the first choice is radical surgery. The radicality of the excision is similar to malignant melanoma, that is, wide enough with a safety margin of $2-5 \mathrm{~cm}$. For very rare tumors and difficult preoperative clinical diagnosis, after histopathological verification, reoperation is usually required. The radicality of the treatment is proportional to the stage of the disease (Table 1) (ref. ${ }^{32}$ ). In the first and second stages without nodal or distant metastasis, radical excision is performed, accompanied in patients at risk by radiotherapy. In the third stage, where locoregional metastases have occurred, expanding output using draining lymph node removal followed by radiotherapy is done. The total radiation dose is usually $45-65 \mathrm{~Gy}$ (ref. ${ }^{33,34}$ ). In the fourth stage, or presence of distant organ metastases, the treatment is palliative involving chemotherapy, supplemented by radiotherapy. The tumor frequently metastasizes to the lungs, liver and bones. The chemotherapeutic agents most commonly used are etoposide and carboplatin ${ }^{35}$. The most recent treatment for MCC is biological (cetoximab) ( ref. $^{36}$ ). Another potential therapeutic option is use of the anti-tumor apoptopic and interferon alfa ${ }^{37}$. After treatment, vital is follow up at regular monthly intervals in the first year, then at quarter year intervals. The total length of the follow-up should be at least five years.

The prognosis is not good but depends on the stage of disease at the time of initiation of treatment. Five-year survival of I. - II. stage is suggested to be up to $75 \%$, III. stage in $59 \%$ and presence of distant metastases, or IV. stage, only $25 \%\left(\right.$ ref. $\left.^{38}\right)$.

\section{DISCUSION}

As mentioned above, MCC is presumed to be based on the Merkel cell (MC), whose origin is not entirely clear². Second, among Merkel tumor cells there are morphological and biological differences. The frequent presence of neuroendocrine granules, and positivity for cytokeratin 20 (CK - 20) in the case MCC provide evidence that the tumor is based on the MC (ref. ${ }^{39}$ ). However, the MC and MCC differ in the characteristic of neurofilaments which are only visible in MCC. Another argument supporting the distinction between $\mathrm{MC}$ and $\mathrm{MCC}$, is the characteristic picture of mitosis which is not apparent in the Merkel cell ${ }^{40}$. There are also differences in the localization of tumor and Merkel cells. While the tumor is located practically only in the dermis, Merkel cells are present exclusively in epidermal structures. The question in the debate also remains the cause of the malignant change. One subject of study is the cause of alteration in growth factors, such as $\alpha$-PDGF (platelet-derived growth factor- $\alpha$, which has a major role in angiogenesis). Swicka et al. ${ }^{41}$ showed a mutation of PDGF receptor- $\alpha$. In contrast, activating mutations eliminate the c-kit (CD117 syn.) cytokin receptor on the surface of hematopoietic cells, strongly associated with SCF (stem cell factor) important for the assessment of cell differentiation. The tumor tissue also demonstrates high expression of VEGF receptors (vascular endothelial growth factor), specifical1y, VEGF-A (91\%), VEGF-C (75\%) and VEGF-R2 (88\%) $\left(\right.$ ref. $\left.^{42}\right)$. Essential for tumor formation is the failure of cell cycle regulation. In general, important regulators of the cell cycle, preventing uncontrolled cell division, are retinoblastoma protein $(\mathrm{RB})$, factors that inhibit proliferation and tumor suppressor protein p53 as a suppressor gene product inhibits cell proliferation and induces apoptosis ${ }^{43}$. Both factors are considered crucial tumor suppressor mechanisms and their failure is essential for the emergence of a tumor. Mutations of p53 in MCC have been detected only sporadically which contrasts with p53 mutations in other tumors where they may be up to $50 \%$ (ref. ${ }^{44,45}$ ). Mutations in p63, a relative of the p53 "family" in MCC significantly correlate with tumor aggressiveness ${ }^{46}$. As mentioned, MCC can form in patients with weakened immune systems. The Merkel Cell Polyomavirus (MCPyV) was described for the first time in January 2008 as one of seven known human viruses that play a role in malignant disease ${ }^{8}$. After the integration of viral DNA into the cellular genome occurs and the exprimed small and large $\mathrm{T}$ antigen are multifunctional proteins. Large $\mathrm{T}$ antigen binds to the cell cycle regulator and tumor suppressor proteins p53 and RB,thereby inactivating which results in in stimulation of the cell cycle and the start of oncogenesis. It has become clear however that the virus MCPyV seroprevalence among the general 
population is high. Any direct effect of the virus on cancer therefore remain controversial. From a prognostic point of view, positive MCPyV in MCC is unclear and opinions differ.

In the treatment of MCC, prevention plays a crucial role and early excision of the tumor extension. The excision of the tumor using Mohs micrographic surgery was first described by Frederick Mohs in $1930 \mathrm{~s}^{47}$. The principle of tumor excision is a sharp curette, and other progressive verification of positivity of edges under the microscope. Samples of tissue are taken from the dermis, where the tumor is located until the resection margins are negative and the defect can be reconstructed. Mohs micrographic technique has been recommended especially in areas with high demands on aesthetics, such as localized tumors of head and neck. Brisset et al. ${ }^{48}$ however, point to the lower survival of patients treated with Mohs technique compared to patients with extensive radical excision supplemented by cervical block dissection.

Even though the general nature of the tumor is rapid growth and early metastases, there are published data on spontaneous regression ${ }^{49}$. Mori et al. ${ }^{50}$ observed high apopoptic tumor activity in 8 cases of patients treated for MCC. Inoue et al. ${ }^{51}$ studied the mechanism of spontaneous regression in 7 patients ( 4 patients with spontaneous regression, 3 without spontaneous regression). The study looked at a number of parameters (TUNEL index, labeling index of proliferating cell nuclear antigen (PCNA) labeling index of bcl-2 protein expression of p53 in tumour cells) and extent of lymphocytic infiltration around the tumor. The number of T lymphocytes in the infiltrate was higher in patients with spontaneous regression than in patients where no regression occurred. The frequency of T-lymphocytes in the infiltrate around the tumor is therefore considered one of the main causes of spontaneous regression.

\section{CONCLUSION}

Merkel cell carcinoma is a rare malignancy with an uncertain prognosis. Due to the rare occurrence and dearth of randomized studies, optimal treatments are generally not known. The tumor has only recently been included in the international classification of tumors ( $\mathrm{NCCN})$. The basis of successful treatment remains prevention, consisting of regular dermatological examination in immunosuppressed patients and early initiation of combination therapy, based on radical surgery supplemented by radiotherapy and chemotherapy in the last resort.

\section{REFERENCES}

1. Toker C. Trabecular carcinoma of the skin. Archives for dermatological research 1972;105:107-10.

2. Van Keymeulen A, Mascre G, Youseff KK. Epidermal progenitors give rise to Merkel cells during embryonic development and adult homeostasis. Journal of cell biology 2009;187(1):91-100.

3. Mottl H, Abrahamová J. Nádor z Merkelových buněk u dvouleté dívky-kazuistika. Klinická onkologie 1990;3(1):19-21.
4. Schmid C, Beham A, Feichtinger J. Recurrent and subsequently metastasizing Merkel cell carcinoma in a 7-year-old girl. Histopathology 1992;20(5):437-9.

5. Hodgson NC. Merkel cell carcinoma: changing incidence trends. Journal of surgical oncology 2005;89(1):1-4.

6. Brenner B, Sulkes A, Rakowsky E. Second neoplasmas in patients with Merkel cell carcinoma. Cancer 2001;91:1358-62.

7. Buel JF, Gross TG, Woodle ES. Malignancy after transplantation. Transplantation 2005;15:254-8.

8. Feng $\mathrm{H}$, Shuda $\mathrm{M}$, Chang $\mathrm{Y}$. Clonal integration of polyomavirus in human Merkel cell carcinoma. Science 2008;319(5866):1096-100.

9. Pages F, Berger A, Camus M. Effector memory T cells, early metastasis and survival in colorectal cancer. New England journal of medicine 2005;353:2654-6.

10. Dantal J, Huormant M, Cantarovich D. Effect of long-term immunosuppression in kidney-graft recipients on cancer incidence: randomised comparison of two cyklosporin regiments. Lancet 1998;351:623-8.

11. Goepfer H, Remmier D, Silva E, Wheller B. Merkel cell carcinoma (endocrine carcinama of the skin) of the head and neck. Archives of otolaryngology 1984;110:707-12.

12. Medina-Franco $\mathrm{H}$, Urist MM, Fiveash J. Multimodality treatement of Merkal cell carcinoma: case series and literature review of 1024 cases. Annals of surgical oncology 2001;8:204-8.

13. Helmbold $\mathrm{P}$, Schöter $\mathrm{S}$, Holzhausen $\mathrm{HJ}$, et al. Merkel cell carcinoma: a diagnostic and therapeutic challenge. Chirurgia 2001;72:396-401.

14. Tai PT, Yu E, Tonita J, et al. Merkel cell carcinoma of the skin. Journal of Cutaneus Pathology 2000;4(4):186-96.

15. Vantuchová Y. Karcinom z Merkelových buněk. Dermatologie pro praxi 2008;2(1):23-5.

16. Johansson L, Tennvall J, Akerman M. Immunohistochemical examination of 25 cases of Mekel cell carcinoma: comparison with small cell carcinoma of the lung and oesophagus, and a review of the literature. APMIS 1990;98:741-52.

17. Schmidt U, Muller U, Metz KA, Leder LD. Cytokeratin and neurofilament protein staining in Merkel cell carcinoma of the small cell type and small cell carcinoma of the lung. Americal Journal of dermatopathology 1998;20:346-51.

18. Miettinen M. Keratin 20: immunohistochemical marker for gastrointestinal, urothelial and Merkel cell carcinimas. Modern Pathology 1995;8:384-88.

19. Scott MP, Helm KF. Cytokeratin 20: a marker for diagnostic Merkel cell carcinoma. Americal Journal of Dermatopathology 1999;21:16-20.

20. Lazzaro D, Price M, de Felice M, Di Lauro R. The transcription factor TTF-I is expressed at the onset of thyroid and lung morphogenesis and in restricted regions of the foetal brain. Development 1991;113:1093-104.

21. Byrd-Gloster AL, Khoor A, Glass LF, Messina JL, Whitsett JA, Livigston SK, Cagle PT. Differential expression of thyroid factor TTF-I in small lung carcinoma and Merkel cell tumor. Human Pathology 2000;31:58-62.

22. Metz KA, Jacob M, Schmidt U, Steuhl KP, Leder LD. Merkel cell carcinoma of the eyelid: histological and immunohistochemical features with special respect to differential diagnosis. Graefes Archive for Clinical and Experimental Ophthalmology 1998;236:561-66.

23. Leong AS, Phillips GE, Pieterse AS, Milios J. Criteria for the diagnosis of primary endocrine carcinoma of the skin (Merkel cell carcinoma). A histological, immunohistochemical and ultrastructural study of 13 cases. Pathology 1986;18:393-99.

24. Kurokawa M, Nabeshima K, Akiyama Y, Maeda S, Nishida T, Nakayama F, Amano M, Ogata K, Setoyama M. CD56: a useful marker for diagnosing Merkel cell carcinoma. Journal of Dermatological Science 2003;31:219-24.

25. Gallego R, Garcia-Caballero T, Fraga M, Beiras A, Forteza J. Neural cell adhesion molecule immunoreactivity in Merkel cells and Merkel cell tumours. Virchows Archiv 1995;426:317-21.

26. Koljonen V, Haglund C, Tukiainen E, Bohling T. Neuroendocrine differentiation in primary Merkel cell carcinoma--possible prognostic significance. Anticancer Research 2005;25:853-8.

27. Liu Y, Sturgis CD, Grzybicki DM, Jasnosz KM, Olson PR, Tong M, Dabbs DD, Raab SS, Silverman JF. Microtubule-associated protein-2: a new sensitive and specific marker for pulmonary carcinoid tumor and small cell carcinoma. Modern Pathology 2001;14:880-5.

28. Liu Y, Saad RS, Shen SS, Silverman JF. Diagnostic Value of 
Microtubule-Associated Protein-2 (MAP-2) for Neuroendocrine. Neoplasms advances in anatomic pathology 2003;10:101-6.

29. Liu Y, Mangini J, Saad R, Silverman AR, Abell E, Tung MY, Graner SR, Silverman JF. Diagnostic value of microtubule-associated protein-2 in Merkel cell carcinoma. Applied immunohistochemistry molecular morphology 2003;11:326-9.

30. Tarkkanen M, Knuutila S. The diagnostic use of cytogenetic and molecular genetic techniques in the assessment of small round cell tumours. Current Diagnostic Pathology 2002;8:338-48.

31. Pisick E, Skarin AT, Salgia R. Recent advances in the molecular biology, diagnosis and novel therapies for various small blue cell tumors. Anticancer Research 2003;23:3379-96.

32. Shaw JH, Rumball WB. Merkel cell tumour: clinical behavior and treatment. British journal of Sumery 1991;78(2):138-42.

33. Leonard JH, Ramsay JR, Kearsley JH, Birrell GW. Radiation sensitivity of Merkel cell carcinoma cell lines. International Journal of Radiation Oncology 1995;32:1401-7.

34. Herbst A, Haynes HA, Nghiem P. The standard of care for Merkel cell carcinoma should include adjuvant radiation and lymph node surgery. Journal of the American academy of dermatology 2002;46:6402.

35. Tai PT, Yu E, Winquist E, Hammond A, Stitt L, Tonita J, Gilchrist J.. Chemotherapy in neuroendrine/Merkel cell carcinoma of the skin: case series and review of 204 cases. Journal of clinical oncology 2000;18(12):2493-9.

36. Maubec E, Duvillard P, Velasco V, Crickx B, Avril MF Immunohistochemical analysis of EGFR and HER-2 in patiens with metastasis squamous cell carcinoma of the skin. Anticancer Research 2005;25(2B):1205-10.

37. Krasagakis K, Krüger-Krasagagis S, Tzanakakis GN, Darivianaki K Stathopoulos EN, Tosca AD. Interferon-alfa inhibits prolifaration and induces apoptosis of Merkel cell carcinoma in vitro. Cancer Investigation 2008;26(6):562-8.

38. Eng TY, Boersma MG, Fuller CD, Cavanaugh SX, Valenzuela F, Herman TS. Treatment of Merkel Cell carcinoma. American Journal of Clinical Oncology 2004; 27(5):510-5.

39. Sadahira Y, Nakamoto S, Mori M, Hsueh CL, Awai M. Merkel cell tumor coexpressing cytokeratin and neurofilament proteins. Acta pathologicy japn 1987;37:331-7.

40. Vaigot $P$, Pisani A, Darmon YM, Ortonne JP. The majority of epidermal Merkel cells are non-proliferative: a quantitative immunofluorescence analysis. Acta dermatologica venerologica 1987;67:517-20.
41. Swick BL, Ravdel L, Fitzpatrick JE, Robinson WA. Platelet-derived growth factor receptor alpha mutational status and immunohistochemical expression in Merkel cell carcinoma: implications for treatment with imatinib mesylate. Journal of Cutaneous Pathology. 2008;35(2):197-202.

42. Brunner M, Thurnher D, Pammer J, Geleff S, Heiduschka G, Reinisch CM, Petzelbauer P, Erovic BM. Expression of VEGF-A/C, VEGF-R2, PDGF-alpha/beta, c-kit, EGFR, HER-2/Neu, Mcl-1 and Bmi-1 in Merkel cell carcinoma. Modern Pathology 2008;21(7):876-84.

43. Horn HF, Vousden KH. Coping with stress: multiple ways to activate p53. Oncogene 2007;26(9):1306-16.

44. Popp S, Waltering S, Herbst C, Moll I, Boukamp P. UV- B-type mutations and chromosomal imbalances indicate common pathways for the development of Merkel and skinsquamous cell carcinomas. International Journal of Cancer 2002;99(3):352-60.

45. Van Gele M, Kaghad M, Leonard JH, Van Roy N, Naeyaert JM, Geerts ML, Van Belle S, Cocquyt V, Bridge J, Sciot R, De Wolf-Peeters C, De Paepe A, Caput D, Speleman F. Mutation analysis of P73 and TP53 in Merkel cell carcinoma. British Journal of Cancer 2000;82(4),823-6.

46. Asioli S, Righi A, Volante M, Eusebi V, Bussolati G. p63 expression as a new prognostic marker in Merkel cell carcinoma. Cancer 2007;110(3):640-7.

47. Cottel WI, Bailin PL, Albom MJ, Bernstein G, Braun M, Hanke CW, Sutnick TB, Swanson NA. Essentials of Mohs micrographic surgery. Journal of dermatologic surgery and oncology. 1988;14:11-13.

48. Brissett AE, Olsen KD, Kasperbauer JL, Lewis JE, Goellner JR, Spotts $\mathrm{BE}$, Weaver AL, Strome SE. Merkel cell carcinoma of the head and neck: a retrospective case series. Head Neck 2002;24:982-8. doi: 10.1002/hed.10153.

49. Connelly TJ, Cribier B, Brown TJ, Yanguas I. Complete spontaneous regression of Merkel cell carcinoma: a review of the 10 reported cases. Dermatologic Surgery 2000;26:853-6.

50. Mori Y, Hashimoto K, Tanaka K, Cui CY, Mehregan DR, Stiff MA. A study of apoptosis in Merkel cell carcinoma: an immunohistochemical, ultrastructural, DNA ladder, and TUNEL labeling study American Journal of dermathopatology 2001;23:16-23.

51. Inoue T, Yoneda K, Manabe M, Demitsu T. Spontaneous regression of merkel cell carcinoma: a comparative study of TUNEL index and tumor-infiltrating lymphocytes between spontaneous regression and non-regression group. Journal of Dermatological Science 2000;24:203-11. 